\title{
DETERMINANTS OF THE EXPORTS OF HUNGARY: TRADE THEORY AND THE GRAVITY MODEL*
}

\author{
László ERDEY - Andrea PÖSTÉNYI \\ (Received: 7 July 2016; revision received: 9 October 2016; \\ accepted: 29 October 2016)
}

The end of the Communist regime brought about great changes in the economies of Central and Eastern Europe; the restructuring of foreign trade was one of the biggest challenges for these countries. After the transition period, Hungary became a very open country, with its trade to GDP ratio around 1.5, while trading with more than 190 countries. The aim of this paper is to analyse the determinants of exports between 1993-2014, with an emphasis on the impact of factor endowments. According to our results, economic size, common border, and free trade agreements had a statistically significant positive effect on exports, while the coefficient of distance had the expected negative sign. We measured factor endowments with several approaches and our results show that exports change in line with the Linder hypothesis, i.e. Hungary tends to trade more with countries having similar factor endowments, and thus its trade is based on differentiated products.

Keywords: factor endowments, Heckscher-Ohlin model, Linder hypothesis, gravity model

JEL classification indices: F11, F14

* The present paper is a significantly revised version in its empirical approach of our previous paper presented at the SSEM EuroConference, Budapest, July 6-8, 2014. The recommendations of the two anonymous referees are highly appreciated.

László Erdey, corresponding author. Associate Professor, Head of Department of World Economy and International Relations, Faculty of Economics and Business, University of Debrecen.

E-mail: erdey.laszlo@econ.unideb.hu

Andrea Pöstényi, Senior Financial Accounting and Reporting Analyst at ExxonMobil.

E-mail: andrea.postenyi@gmail.com 


\section{INTRODUCTION}

Hungary is a small Central European country that became a market economy in 1989, after the end of the Communist regime. The last 25 years differed greatly from the Communist era in both political and economic terms; one of the most noticeable changes was the structural change in foreign trade as the country started to trade with more advanced economies. This paper analyses the determinants of the foreign trade after the transition period, and its purpose is to determine which trade theory corresponds to the trade flows of Hungary regarding factor endowments.

Empirical studies became widespread after the famous finding of Leontief (1953) on trade and factor endowments in the United States, which was in contradiction with the Heckscher-Ohlin model. Leamer (1980) suggested that Leontief merely misinterpreted the H-O model, hence there was no paradox. Since then, countless empirical studies (e.g. Krugman - Obstfeld 1988; Trefler 1993) found evidence against the $\mathrm{H}-\mathrm{O}$ model. One question still remains: whether the $\mathrm{H}-\mathrm{O}$ model is inconsistent with the foreign trade of small, open transition countries as well. In our analysis, we used the gravity model of trade. Similar studies include Rahman (2003), Schumacher (2003), and Sohn (2005); we followed the methodology of Eicher et al. (2012) and Shirotori et al. (2010). Our empirical results confirm the previous findings: the greater the differences in the factor endowment variables, the less the trade volume between Hungary and its trading partners, therefore the H-O model is inconsistent in the case of Hungary, too.

The paper is organised as follows. Section 2 discusses the theoretical background of the relationship between factor endowment and trade theory, and the evolution of the gravity model, Section 3 gives an overview of the foreign trade of Hungary. Section 4 presents the methodology and data of the empirical analysis along with the results, and Section 5 concludes.

\section{FACTOR ENDOWMENT, THE LINDER HYPOTHESIS AND TRADE THEORY, AND THE EVOLUTION OF THE GRAVITY MODEL}

When we refer to Heckscher-Ohlinian or Linder-type trade models, we differentiate between the traditional and new explanations of international trade. From a chronological point of view, the classical Ricardian theory that explains international trade with technological differences between countries was the first of the models. Although the original model is more than 200 years old, the multi-country and multi-product versions were born much later and were only recently subjected to deeper empirical testing (Eaton - Kortum 2002; Costinot et al. 2012). In 
this paper we follow Hausmann et al. (2014) and consider the Ricardian model as a reduced form of the more general Heckscher-Ohlin-Vanek (Vanek 1968) model, where labour productivities are determined by the availability of other factors of production. In its most basic forms, the original Heckscher-Ohlin model stresses the differences in factor endowments as the cause of international specialisation. Different relative marginal costs of production caused by factor endowment differences induce countries to export goods which require their abundant and import those which contain their scarce factors. Leamer (1992) stressed two important empirical findings leading to two new discoveries, namely the Leontief paradox which showed that US imports were more capital intensive than exports, while the other was the emergence and growing volumes of intra-industry trade. These findings led to the modification and amplifications of the Heckscher-Ohlin model (e.g. the reformulation by Vanek regarding the factor content of trade; Trefler 1993, 1995; Davis at al. 1997; Davis - Weinstein 2001; Antweiler - Trefler 2002; Trefler - Zhu 2010). At the same time, the researchers made push to the construction of new trade theory models based on imperfect competition with differentiated products and increasing returns to scale which we will refer to as Linder-type models, acknowledging the original insight of Linder (1961), which is the oldest theory of product quality in international trade. Linder hypothesised that potential exports are determined by domestic demand since strong local demands for a good are required for investors to induce investments in a sector, which would lead to exports to countries with similar consumption patterns. Almost two decades later, new trade theory models based on the works of Spence (1976), Dixit - Stiglitz (1977), Krugman (1979, 1981), Lancaster $(1979,1980)$, and Helpman Krugman (1985) were able to explain horizontal and vertical intra-industry trade (for the origins of the latter, see Falvey 1981; Falvey - Kierzkowski 1987; Flam - Helpman 1987; Shaked - Sutton 1984).

Although empirical research shows a clear upward trend of global intra-industry versus inter-industry trade even in the case of some lower-income (mostly Asian) countries (see, inter alia, Brülhart 2009 for a comprehensive analysis), the relationship between factor endowment differences and trade types (i.e. inter-industry, horizontal, and vertical intra-industry trade) remains insufficiently explained. While there is a broad, theoretically and empirically supported consensus since long decades that relative factor endowment differences enhance or are the very reason behind inter-industry trade (except in the case of possible factor intensity reversals) and also that the stronger prevalence of horizontal intra-industry flows can be expected between countries with more similar relative endowments, there is no unquestionable monotonic relationship between the share of vertical intraindustry trade and factor endowments (see Gabszewicz et al. 1981; Shaked - Sutton 1984; Motta 1994; Gabszewicz - Turrini 1997; Haucap et al. 2000; Cabral et 
al. 2013 for at least some slightly different approaches compared to the former "consensus" on its existence).

While traditional trade theories adopted a country as its basic unit of analysis, new trade theories focused on industries. "New new trade" theories of the last decade stressed the importance of firm-level differences within industries (Melitz 2003; Bernard et al. 2003, 2007) producing differentiated goods.

The gravity model became popular in the last 30 years for being a quite simple instrument for explaining trade patterns. As the name of the model suggests, the gravity model of trade derives from the gravity model known from physics. Tinbergen (1962) was the first to use the gravity model for assessing trade: he concluded that the most determining factors of the optimal level of trade are the economic size of the two countries (GNP) and the distance between them. It was Anderson (1979) who laid down the theoretical foundations of the model: the starting point was a gravity equation and he derived the gravity equation from the properties of expenditure systems. His gravity model was the following:

$$
M_{i j k}=\alpha_{k} Y_{i}^{\beta_{k}} Y_{j}^{\gamma_{k}} N_{i}^{\varepsilon_{k}} N_{j}^{\varepsilon_{k}} d_{i j}^{\mu_{k}} U_{i j k},
$$

where $M_{i j k}$ is the flow of good or factor $k$ from country or region $i$ to country or region $j$ expressed in dollars, $Y_{i}$ and $Y_{j}$ are the income of country or region $i$ and $j$, $N_{i}$ and $N_{j}$ are the population of country or region $i$ and $j, d_{i j}$ is the distance between country or region $i$ and $j$, while $U_{i j k}$ is a lognormally distributed error term with an expected value of 0 . According to the gravity equation, bilateral trade depends on the economic sizes and the bilateral barriers between country or region $i$ and $j$. Considering given bilateral trade barriers, the higher the barriers between $j$ and its other trading partners, the more the reduction in the relative price of products from country $i$, and thus the import from country $i$ increases. Based on the gravity equation, trade between two countries is determined by the relative trade barriers: bilateral trade depends on the relationship of bilateral barriers between these two countries and the average trade barriers with other trading partners. This average trade barrier is called multilateral resistance. Trade is more important for smaller countries, therefore trade barriers have a greater impact on their multilateral resistance (Anderson - van Wincoop 2001).

According to Anderson (2010), a typical gravity model contains the logarithm of bilateral trade as the dependent variable, and the explanatory variables are the logarithm of GDP, population, and distance. Additional variables may be necessary, depending on the purpose of the analysis, although some of them might have a great explanatory power without theoretical grounds.

The main aim of this study is to determine which trade theory holds when assessing the foreign trade of Hungary, and thus the gravity equation is augmented by adding variables capturing factor endowment. One variable that indicates the 
factor endowment of a country is the per capita income. Adding GDP per capita to the model reveals the link between a country's trade and its stage of development. Bergstrand (1989) applied the gravity equation in a multi-industry setting and found that if the elasticity of substitution exceeds unity, the positive coefficient for the exporter's per capita income indicates the industry to be capital intensive, while a positive coefficient for the importer's per capita income indicates that the industry's output is a luxury in consumption. A negative coefficient for the exporter's per capita income refers to labour intensity, while a negative coefficient for the importer's per capita income reveals that the industry's output is a necessity in consumption.

Montenegro - Soto (1996), Rahman (2003), and Batra (2006) used the absolute value of difference of the two countries' income per capita to determine whether the H-O model or the Linder hypothesis explains the pattern of bilateral trade flows. The Heckscher-Ohlin model states that countries with dissimilar levels of output will trade more than countries with similar levels, while the Linder hypothesis asserts that countries with similar levels of income per capita will have similar preferences and will thus trade more with each other. The positive sign of the coefficient refers to the $\mathrm{H}-\mathrm{O}$ model, while the negative sign to the Linder hypothesis. Montenegro - Soto (1996) found evidence supporting the Linder hypothesis for the foreign trade of Cuba in the period of 1980-1991. A similar result was obtained by Batra (2006) in the case of India for the year 2000. In contrast, Rahman (2003) analysed the foreign trade of Bangladesh for the period of 1972-1999 and got positive coefficients for the variable capturing the per capita differential between the two countries; thus, the foreign trade of Bangladesh corresponds to the H-O model. Baskaran et al. (2011) augmented the gravity equation by adding the absolute difference of the capital-labour ratio of countries $i$ and $j$ from the Penn World Table, and analysed the trading system as a scale-free network for 28 product groups for the period of 1980-2000. They found negative coefficients for the factor endowment variables rejecting the $\mathrm{H}-\mathrm{O}$ model; however, augmenting the model with the interaction between the factor differential and the network variable resulted in much more favourable coefficients with regard to the $\mathrm{H}-\mathrm{O}$ model.

\section{THE FOREIGN TRADE OF HUNGARY: AN OVERVIEW}

Köves (2003) already demonstrated that World Wars I and II and the post-socialist transition, starting in the late 1980s and the early 1990s changed the geographic structure of Hungary's international trade. On the eve of World War I, Hungary's most important trading partner was Austria. After about 25 years, in 1938, Hun- 
gary's most important trading partners were Germany and its political allies, Italy and Austria. The period after World War II was dominated by the Soviet Union, and Eastern European CMEA countries.

From the mid-1990s, we witness an era characterised by very dynamically increasing trade volumes, with only two setbacks in 2004 and 2009. The former might be partly due to methodological changes ${ }^{1}$ and the second was obviously an impact of the international financial crisis.

In spite of increasing trade volumes, Hungary's trade openness indices (exports/GDP, imports/GDP, and trade turnover/GDP ratios) were slightly decreasing from the mid-1970s until the beginning of the high trade dynamism era from the mid-1990s (Figure 1).

Merchandise trade (as a percentage of GDP) was $82 \%$ and shrinking until 1993, surpassing its starting level only in 1997. From that time on, dynamism seemed almost unstoppable, reaching $157 \%$ by 2015 , making Hungary one of the most open countries in the world.

The last 20 years changed the geographical structure of Hungary's foreign trade once again. Liberalisation was fast and deep. ${ }^{2}$ The reorientation of trade was greatly facilitated by the Europe Agreement - removing protectionist measures for most of Hungary's trade with the EC (EU) - and the creation of the Central European Free Trade Agreement. Turning towards developed markets at the same time was coerced by the transformational recession and liberalisation of the former socialist countries, which significantly decreased the demand for products imported from Hungary. The reorientation was successful. Liberal policies towards foreign direct investment linked the country to the global production system of multinational companies. The shifting geographic structure of trade reflects these changes. ${ }^{3}$ Between 1993 and 2003, the share of developed countries in Hungarian exports and imports reached $70 \%$ and $80 \%$, respectively. At the same time, the EU (first 12 and, from 1995, 15 countries) became the most important trading partners.

Between 2003 and 2006, the share of EU-25 (the 25 countries constituting the EU from 2004 to 2007 ) decreased from $76 \%$ to $68 \%$ in imports and from $81 \%$ to $74 \%$ in exports, with the growing share of extra-EU, mostly Asian countries (the growth of China's share was more than twofold). The last period analysed in this

1 Concerning trade data reported by the Hungarian Central Statistical Office (HCSO), it must be noted that there were two important changes in the compilation of external trade data. Since the 1997 review, trade between industrial free zones and foreign markets was taken into account. From 2004, the compilation has been adapted to the methodology of the EU. See http:// www.ksh.hu/docs/eng/modsz/modsz35.html (accessed 04/02/2017).

2 See, for example, Bock (1995), Nagy (1995) and WTO (1998).

3 The following section contains the authors' own calculations based on HCSO data. 


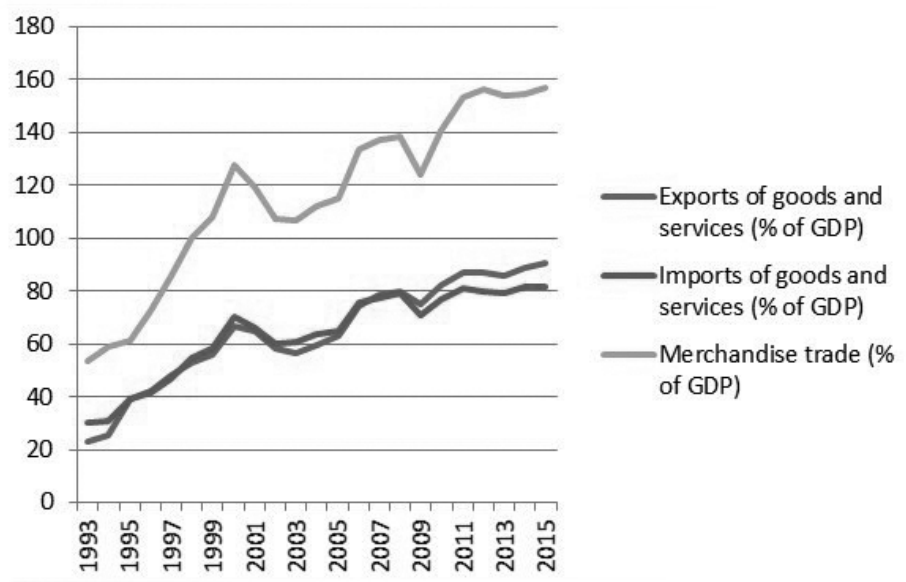

Figure 1. Indices of Hungary's trade openness, 1993-2015 (\%)

Source: World Bank, World Development Indicators.

paper, between 2007 and 2014, is characterised by the share of the EU-27 growing from around $2 / 3$ to $3 / 4$ of imports and a stable $3 / 4$ of exports, with a slightly decreasing role of the core-EU members (EU-15 of 1995) and the growing share of the newly joined member states. Taking a look at the country level, Germany's role is unquestionable once again after the interwar period in the history of foreign economic relations. Germany is responsible for roughly 1/4 of the Hungarian trade turnover.

The commodity structure of trade reflects a developed country setup. In the CMEA division of the labour system, Hungary was an important exporter of manufactured goods and machinery, but this meant relatively low quality goods exported mostly to the Soviet Union. In return, this partner was the largest supplier of fuels, minerals, and other crude materials. By the end of the period, once again, the most important commodity groups in both imports and exports are machinery and transport equipment (46\% and 54\%, respectively in 2014), and manufactured goods (34\% and $32 \%)$. The difference this time is that the Hungarian products are sold on the competitive markets of developed countries. On the import side, fuels and electric energy are significant as well (12\%).

The final part of this section aims to analyse some major characteristics of Hungary's intra-industry/two-way trade after the transition. ${ }^{4}$ Firstly, we calculated the Grubel-Lloyd (1975) indices at two different aggregation levels using the SITC Rev 3 3-digit level for sections 0-8 (257 product groups, excluding

4 The source of data was DESA/UNSD, the United Nation's Comtrade database. 
the high trade volatility commodities and transactions not classified according to kind) and at HS92 6-digit levels (4959 products) to reduce the aggregation bias. We deliberately chose not to control for the geographical bias coming from using bilateral trade between Hungary and the "rest of the world" to get a picture about the general pattern of inter- and intra-industry trade. However, we are aware of the fact that this choice might cause some slight overestimation of the indices compared to those calculated aggregating the weighted bilateral data with each trading partner. Next, we disentangled the trade flows into one-way, horizontal, and vertical two-way trade (intra-industry, HIIT, and VIIT, respectively) using the Fontagné - Freudenberg - Gaulier $^{5}$ (2005) and the Azhar -Elliott (2004) method. ${ }^{6}$ The indices are reported in Table 1.

The first three columns of Table 1 clearly show a markedly growing tendency of the share of intra-industry flows in Hungary's trade, which became a dominant part even at high levels of disaggregation of the country's international merchandise exchange. High GL indices demonstrate evidence for a growing economic similarity to its major trading partners. Two-way trade can be disentangled into two parts. Horizontal intra-industry trade is the two-way trade of similar versions of the same product that are differentiated by secondary attributes (e.g. design, etc.), but not primarily by quality and price. In the case of vertical intra-industry trade, we may observe and measure the two-way flows of product versions differing in quality and price. The growing indices of the horizontal type suggest that the consumption patterns of Hungary and its major trading partners became more similar and that the country enhanced its ability to exploit agglomeration and economies of scale effects in the production. High and stable shares of vertical two-way trade are in line with increased levels of the transnationalisation of the Hungarian economy, that is the supply side of the economy became a highly integrated part of the international production network of multinational companies.

\section{EMPIRICAL ANALYSIS WITH THE GRAVITY MODEL}

In 2014, Hungary traded with more than 190 countries, but due to data availability, our analysis consists of 79 countries, ${ }^{7}$ accounting for $93.7 \%$ of total exports.

\footnotetext{
With $\gamma=10 \%$ and $\alpha=25 \%$ parameters.

With $\gamma=10 \%$ and $\alpha=15 \%$ parameters.

Albania, Argentina, Australia, Austria, Bangladesh, Barbados, Brazil, Bulgaria, Cambodia, Canada, Chile, China, Colombia, Costa Rica, Croatia, Cyprus, Czech Republic, Denmark, Dominican Republic, Ecuador, Egypt, El Salvador, Finland, France, Gabon, Germany, Ghana, Greece, Guatemala, Honduras, Hong Kong, Iceland, India, Indonesia, Ireland, Italy, Japan, Jordan, Kazakhstan, Kenya, Korea, Latvia, Lithuania, Malaysia, Malta, Mauritius, Mexico,
} 


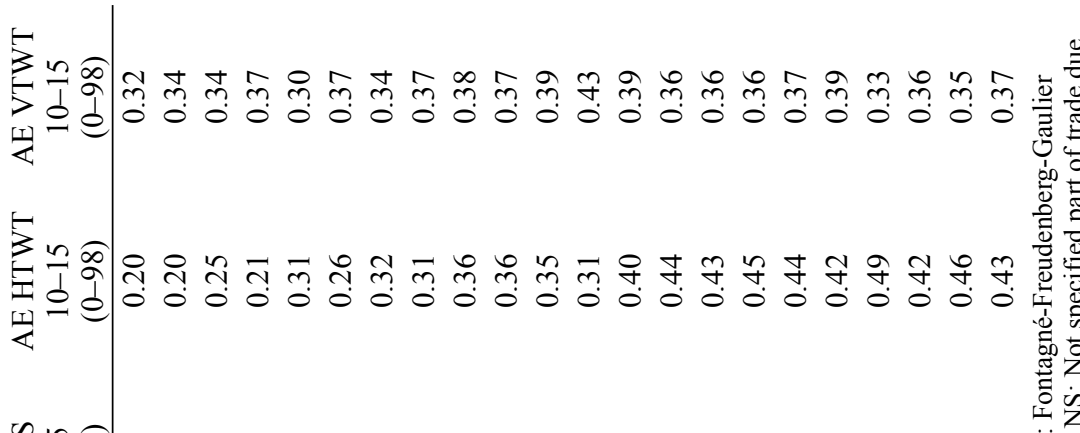

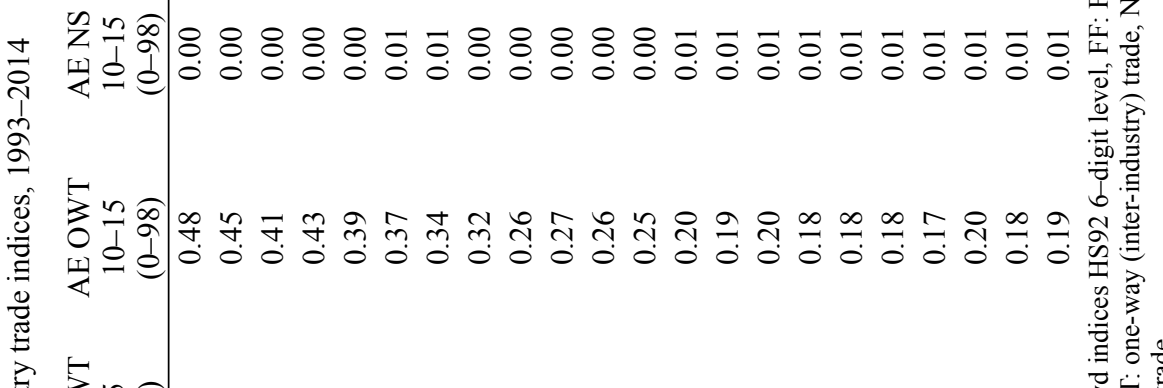

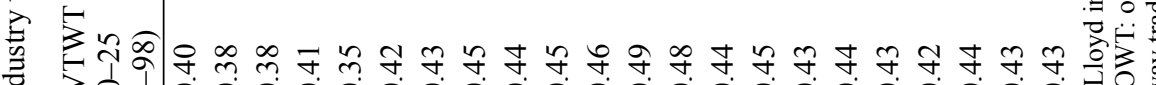
$>$ 先

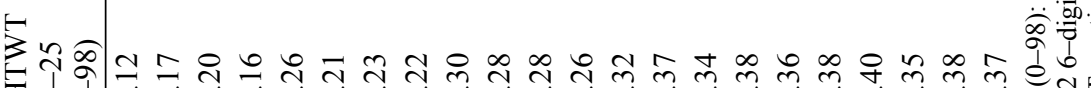

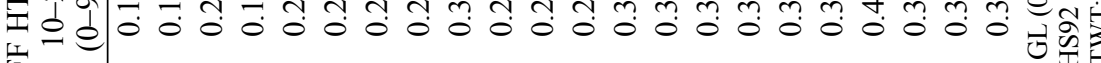
空

i

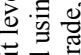

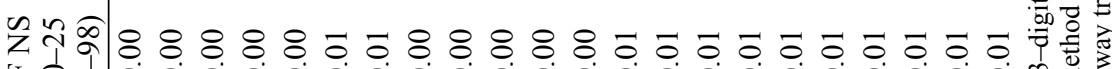

出 0 当

主

$\frac{8}{8}$

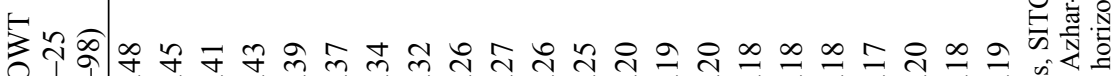

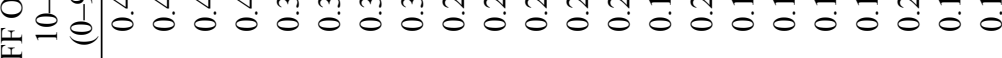

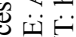

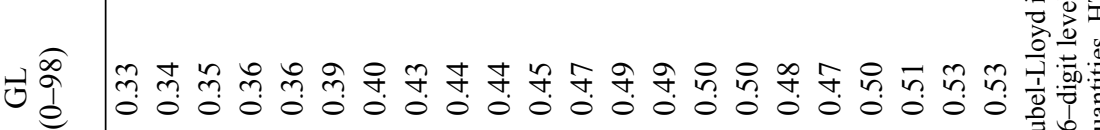

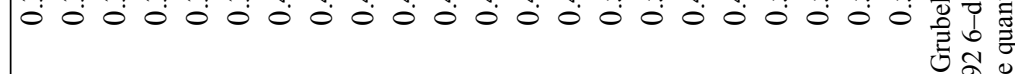

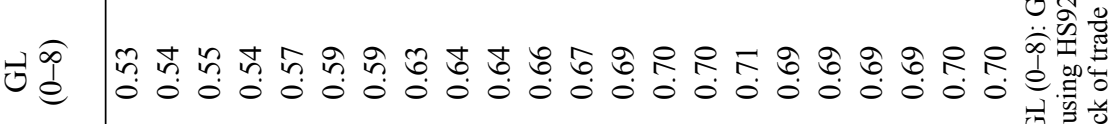
守害苛

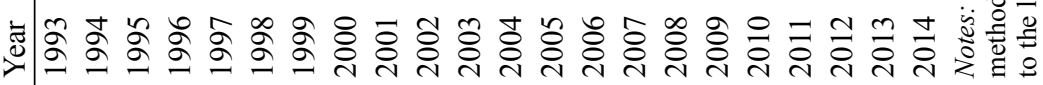


The time period of this analysis is from 1993 to $2014 .{ }^{8}$ Our analysis starts in 1993 because several trading partners' transition took more time and there was no trade data available for the previous years. 2014 is the upper bound of data availability for most of our variables.

\subsection{Model}

We work with an augmented gravity model not only to capture the usually measured effects on the trade on the country, but also to analyse the effect of factor endowments on trade. In the previous section, we discussed various methods revealing factor endowment effects, and in order to be able to find strong evidence supporting one of the trade theories, we applied three different approaches to capture factor endowments.

\subsubsection{Model I: Factor endowment and GDP per capita}

GDP per capita reflects the stage of development and is a good proxy of factor endowment. According to Reimer - Hertel (2010), if GDP per capita rises by 1 per cent, the capital-labour ratio rises by 0.9 per cent, on average. However, we cannot decide between the H-O model and the Linder hypothesis by using this variable per se. As mentioned in the previous section, many authors applied the difference of GDP per capita, which reflects the per capita similarity and thus the factor endowment similarity of the countries. Antonucci - Manzocchi (2006) and Yip (2012) called this variable relative factor endowment. We followed Eicher et al. (2012) in calculating the variable in absolute terms:

$$
\text { AbsRelendow }_{i j t}=\mid \ln \text { GDPpcap }_{i t}-\ln \text { GDPpcap }_{j t} \mid \text {. }
$$

Adding commonly used variables to the basic gravity model and augmenting it by the factor endowment variable, our first equation is the following:

$$
\begin{gathered}
\ln X_{i j t}=\alpha_{0}+\alpha_{1} \ln G D P_{i t}+\alpha_{2} \ln G D P_{j t}+\alpha_{3} \ln D I S T_{i j}+ \\
+\alpha_{4} \text { AbsRelendow }_{i j t}+\beta_{1} C O N T_{i j}+\beta_{2} F T A_{i j t}+e_{i j t}
\end{gathered}
$$

Moldova, Morocco, Mozambique, Nepal, Netherlands, New Zealand, Norway, Panama, Peru, Philippines, Poland, Portugal, Romania, Russia, Saudi Arabia, Singapore, Slovakia, Slovenia, Spain, Sweden, Switzerland, Thailand, Tunisia, Turkey, Uganda, Ukraine, United Kingdom, Uruguay, USA, Venezuela, Vietnam, Zimbabwe.

8 Due to data availability, the time period for Model II is 1993-2011 and 1993-2007 in the case of Model III. 
where $X_{i j t}$ is the bilateral export between country $i$ and $j$, i.e. between Hungary and its trading partner in period $t . G D P_{i t}$ and $G D P_{j t}$ are income of Hungary and its trading partner in dollars, $D I S T_{i j}$ is distance between Hungary and its trading partner (distance of capitals). $C O N T_{i j}$ is the dummy variable for the common border, $F T A_{i j t}$ is a binary variable capturing the effect of a common trade agreement, and $e_{i j t}$ is the error term with expected value of 0 .

\subsubsection{Model II: Factor endowment following the approach of Eicher et al. (2012)}

According to Eicher et al. (2012), proxies based on GDP per capita, population density, and schooling can capture the difference in factor endowments. In their paper, they applied all three variables in the same model, capturing the effect of factor endowment, and therefore we augmented our first model by adding the other two variables.

Besides per capita GDP, education is another factor that reflects the development of countries. We applied the index of human capital from the Penn World Table as a proxy for this type of factor endowment and calculated its absolute difference form in a similar way as before:

$$
\text { AbsHumancapDiff }_{i j t}=\mid \ln \text { Humancap }_{i t}-\ln \text { Humancap }_{j t} \mid \text {, }
$$

where Humancap is the index of human capital per person, based on years of schooling and returns to education. As 2011 is the upper bound for data availability on the index of human capital, the time period for Model II is 1993-2011.

Population density does not necessarily reflect the stage of development, but refers directly to the factor endowment of a country, as it is measured as population divided by the area of a country. The difference of two countries' population densities is calculated as follows:

$$
\text { AbsPopdensDiff }_{i j t}=\mid \ln \text { Popdens }_{i t}-\ln \text { Popdens }_{j t} \mid .
$$

We added these two proxies to our previous equation:

$$
\begin{aligned}
\ln X_{i j t} & =\alpha_{0}+\alpha_{1} \ln G D P_{i t}+\alpha_{2} \ln G D P_{j t}+\alpha_{3} \ln \text { DIST }_{i j}+\alpha_{4} \text { AbsRelendow }_{i j t}+ \\
& +\alpha_{4} \text { AbsHumancap }_{i j t}+\alpha_{4} \text { AbsPopdensDiff }_{i j t}+\beta_{1} \text { CONT }_{i j}+\beta
\end{aligned}
$$

\subsubsection{Model III: Factor endowment with UNCTAD variables}

UNCTAD has a database of factor endowment variables for 135 countries for the period of 1970-2007. Due to data availability, our third model contains 
75 countries $^{9}$ for the period of 1993-2007, accounting for more than 90 per cent in 2007 of total exports. The three variables are physical capital per worker, human capital capturing the average years of schooling, and land area per worker. More information about these variables is available in Shirotori et al. (2010).

We calculated the absolute difference of these variables in the same way as before, and to avoid confusion, we renamed the variable for human capital to AbsSchoolDiff:

$$
\begin{aligned}
\ln X_{i j t}= & \alpha_{0}+\alpha_{1} \ln G D P_{i t}+\alpha_{2} \ln G D P_{j t}+\alpha_{3} \ln \text { DIST }_{i j}+\alpha_{4} \text { AbsPhyscapDiff }_{i j t}+ \\
& +\alpha_{4} \text { AbsSchoolDiff }_{i j t}+\alpha_{4} \text { AbsLandDiff }_{i j t}+\beta_{1} \text { CONT }_{i j}+\beta_{2} .
\end{aligned}
$$

\subsection{Hypothesis}

All three model specifications aim to capture the effect of factor endowments. Our hypothesis is the following: if the coefficients of the factor endowment variables are positive, they support the Heckscher-Ohlin model, i.e. if the difference in the factor endowments of two countries increases, then trade between them will increase as well; if they are negative, the bigger the difference in the factor endowments of the countries, the less they trade with each other, or the more similar these countries' factor endowments are, the more they will trade with each other; in the case of negative coefficients, foreign trade corresponds to the Linder theorem.

\subsection{Data}

Although empirical research suggests the ever increasing share of services in global trade up to $20 \%$ of total global exports (WTO 2015), there are still limits on data availability of trade in services, which places constraints on trade-related research (e.g. Miroudot et al. 2013). In order to avoid serious limitations on the sample size, the dependent variable in our analysis is the export of goods, only.

Another limitation of the calculations and conclusions derives from the application of gross trade data. Evidence shows that due to production fragmentation and the emergence of global value chains (GVCs), foreign content of exports has become significant in the last decades. In parallel, as the result of the OECD and WTO joint initiative, a database has become available on trade in value-added

9 There was no sufficient data for the Dominican Republic, Hong Kong, Moldova, and Singapore; data availability starts in 1994 for Kazakhstan, Latvia, Lithuania, and Ukraine. 
Table 2. Variable description and data sources

\begin{tabular}{lll}
\hline Variable & Description & Data source \\
\hline $\mathrm{X}$ & Export in goods & $\begin{array}{l}\text { UN Comtrade database } \\
\text { (SITC Rev 3.) }\end{array}$ \\
\hline GDP & Gross domestic product & $\begin{array}{l}\text { World Bank database and IMF } \\
\text { WEO April, 2016 }\end{array}$ \\
\hline Dist & Distance & CEPII database \\
\hline AbsRelendow & $\begin{array}{l}\text { Absolute relative factor } \\
\text { endowment }\end{array}$ & $\begin{array}{l}\text { Authors' calculation based on the } \\
\text { World Bank database and IMF } \\
\text { WEO April, 2016 }\end{array}$ \\
\hline AbsHumancapDiff & $\begin{array}{l}\text { Absolute difference of human } \\
\text { capital }\end{array}$ & $\begin{array}{l}\text { Authors' calculation based } \\
\text { on the World Bank database }\end{array}$ \\
\hline AbsPopdensDiff & $\begin{array}{l}\text { Absolute difference of population } \\
\text { density }\end{array}$ & $\begin{array}{l}\text { Authors' calculation based } \\
\text { on the World Bank database }\end{array}$ \\
\hline AbsPhyscapDiff & $\begin{array}{l}\text { Absolute difference of physical } \\
\text { capital per worker }\end{array}$ & $\begin{array}{l}\text { Authors' calculation based } \\
\text { on the UNCTAD database }\end{array}$ \\
\hline AbsSchoolDiff & $\begin{array}{l}\text { Absolute difference of human } \\
\text { capital }\end{array}$ & $\begin{array}{l}\text { Authors' calculation based } \\
\text { on the UNCTAD database }\end{array}$ \\
\hline AbsLandDiff & $\begin{array}{l}\text { Absolute difference of land area } \\
\text { per worker }\end{array}$ & $\begin{array}{l}\text { Authors' calculation based } \\
\text { on the UNCTAD database }\end{array}$ \\
\hline CONT & Common border & \begin{tabular}{l} 
CEPII database \\
\hline FTA
\end{tabular} \\
\hline
\end{tabular}

Notes: GDP data from World Bank database was expanded by IMF WEO data for Venezuela (2013-2014) and Malta (2014).

(TiVA). Value-added trade data suggests that the larger a country, the higher the share of domestic content in its export (Ahmad 2013): while the domestic content of the export of the United States is around 87\%, Eastern European countries have on average $30 \%$ foreign content in their export, and the share of the foreign content of Hungary is even higher, reaching 45\% on average for period 1995-2011 and $48 \%$ in 2011. Since accounting for the content of domestic contribution in foreign trade is quite problematic, data on value-added trade is still very limited and therefore we used gross trade data from the UN Comtrade database. Table 2 contains more information about the variables and the data sources.

\subsection{Empirical results}

We carried out panel analysis for bilateral exports using STATA 13.0. Tables 3 and 4 contain the regression results.

By using simple OLS regression (Table 3), the R-squared reaches 0.80, meaning that our models fit the data quite well; the explanatory variables explain up to 80 per cent of the variability in the dependent variable. Coefficients of the income 
Table 3. OLS regression results

\begin{tabular}{|c|c|c|c|}
\hline & Model I & Model II & Model III \\
\hline $\ln \mathrm{GDP}_{\mathrm{it}}$ & $\begin{array}{l}0.96^{* * *} \\
(11.10)\end{array}$ & $\begin{array}{l}0.95 * * * \\
(9.95)\end{array}$ & $\begin{array}{l}0.91 * * * \\
(6.45)\end{array}$ \\
\hline $\ln \mathrm{GDP}_{\mathrm{jt}}$ & $\begin{array}{l}0.89 * * * \\
(37.49)\end{array}$ & $\begin{array}{l}0.81 * * * \\
(29.34)\end{array}$ & $\begin{array}{l}0.81 * * * \\
(24.49)\end{array}$ \\
\hline $\ln \operatorname{DIST}_{\mathrm{ij}}$ & $\begin{array}{l}-1.50 * * * \\
(-51.37)\end{array}$ & $\begin{array}{l}-1.40 * * * \\
(-37.07)\end{array}$ & $\begin{array}{l}-1.39^{* * *} \\
(-28.85)\end{array}$ \\
\hline $\mathrm{CONT}_{\mathrm{ij}}$ & $\begin{array}{l}0.20 * * \\
(2.01)\end{array}$ & $\begin{array}{c}0.16^{*} \\
(1.66)\end{array}$ & $\begin{array}{l}0.23 * * \\
(2.07)\end{array}$ \\
\hline $\mathrm{FTA}_{\mathrm{ijt}}$ & $\begin{array}{c}0.04 \\
(0.50)\end{array}$ & $\begin{array}{c}0.08 \\
(0.87)\end{array}$ & $\begin{array}{l}0.31 * * \\
(2.44)\end{array}$ \\
\hline AbsRelendow $_{\mathrm{ijt}}$ & $\begin{array}{l}-0.29 * * * \\
(-6.11)\end{array}$ & $\begin{array}{c}-0.09 * \\
(-1.93)\end{array}$ & \\
\hline AbsHumancapDiff $_{\mathrm{ijt}}$ & & $\begin{array}{l}-2.17 * * * \\
(-9.67)\end{array}$ & \\
\hline AbsPopdensDiff $_{\mathrm{ijt}}$ & & $\begin{array}{c}0.04 \\
(0.86)\end{array}$ & \\
\hline AbsPhyscapDiff $_{\mathrm{ijt}}$ & & & $\begin{array}{c}0.03 \\
(0.43)\end{array}$ \\
\hline AbsSchoolDiff $_{\mathrm{ijt}}$ & & & $\begin{array}{l}-0.99 * * * \\
(-6.77)\end{array}$ \\
\hline AbsLandDiff $_{\mathrm{ijt}}$ & & & $\begin{array}{c}-0.13^{*} \\
(-1.88)\end{array}$ \\
\hline Constant & $\begin{array}{l}-16.67 * * * \\
(-7.84)\end{array}$ & $\begin{array}{l}-15.21 * * * \\
(-6.33)\end{array}$ & $\begin{array}{l}-14.35 * * * \\
(-4.08)\end{array}$ \\
\hline Number of obs. & 1738 & 1501 & 1121 \\
\hline Number of var. & 6 & 8 & 8 \\
\hline R-squared & 0.8028 & 0.7993 & 0.7953 \\
\hline
\end{tabular}

Notes: T-statistics in parentheses; ${ }^{*}{ }^{* *},{ }^{* * *}$ denote significance at the 10,5 , and $1 \%$ level, respectively.

variables are statistically significant at the $1 \%$ level and show positive sign: a $1 \%$ increase in the GDP of Hungary or its trading partners increases bilateral export by $0.81-0.96 \%$. While GDP growth has a positive impact on trade, bilateral distance has significantly negative effects; a $1 \%$ increase in the bilateral distance decreases bilateral trade by $1.39-1.50 \%$, ceteris paribus. Sharing a common border or a common free trade agreement has a positive, but rather small effect on bilateral export, although the results for these binary variables are not statistically significant in all cases.

Turning our focus to the effects of the factor endowment variables, Model I shows a statistically significant negative value at the $1 \%$ level, meaning that if the difference in GDP per capita between Hungary and its trading partner increases, bilateral exports between them will decrease. In case of Model II and Model III, only two of the three factor endowment variables give statistically significant re- 
Table 4. Regression results with country- and time-fixed effects

\begin{tabular}{|c|c|c|c|}
\hline & Model I & Model II & Model III \\
\hline $\ln \mathrm{GDP}_{\mathrm{it}}$ & $\begin{array}{l}1.93^{* * *} \\
(13.51)\end{array}$ & $\begin{array}{l}1.22^{* * *} \\
(8.52)\end{array}$ & $\begin{array}{l}1.05^{* * *} \\
(5.97)\end{array}$ \\
\hline $\ln \mathrm{GDP}_{\mathrm{jt}}$ & $\begin{array}{l}0.16^{* * *} \\
(2.62)\end{array}$ & $\begin{array}{l}0.63 * * * \\
(8.04)\end{array}$ & $\begin{array}{l}0.71 * * * \\
(6.90)\end{array}$ \\
\hline $\ln \operatorname{DIST}_{\mathrm{ij}}$ & $\begin{array}{l}-1.51 * * * \\
(-13.63)\end{array}$ & $\begin{array}{l}-1.50 * * * \\
(-6.87)\end{array}$ & $\begin{array}{l}-1.24 * * * \\
(-5.96)\end{array}$ \\
\hline $\mathrm{CONT}_{\mathrm{ij}}$ & $\begin{array}{l}3.35^{* * *} \\
(18.28)\end{array}$ & $\begin{array}{l}1.92 * * * \\
(7.95)\end{array}$ & $\begin{array}{l}1.71^{* * *} \\
(4.55)\end{array}$ \\
\hline $\mathrm{FTA}_{\mathrm{ijt}}$ & $\begin{array}{l}0.21^{* * *} \\
(3.56)\end{array}$ & $\begin{array}{l}0.26^{* * *} \\
(4.14)\end{array}$ & $\begin{array}{l}0.38^{* * *} \\
(4.10)\end{array}$ \\
\hline AbsRelendow $_{\mathrm{ijt}}$ & $\begin{array}{l}-0.15^{* * *} \\
(-3.03)\end{array}$ & $\begin{array}{l}-0.23 * * * \\
(-2.89)\end{array}$ & \\
\hline AbsHumancapDiff $_{\mathrm{ijt}}$ & & $\begin{array}{l}-2.06 * * \\
(-2.19)\end{array}$ & \\
\hline AbsPopdensDiff $_{\mathrm{ijt}}$ & & $\begin{array}{c}0.27 \\
(\mathbf{0 . 8 3})\end{array}$ & \\
\hline AbsPhyscapDiff $_{\mathrm{ijt}}$ & & & $\begin{array}{c}-0.29 \\
(-1.25)\end{array}$ \\
\hline AbsSchoolDiff $_{\mathrm{ijt}}$ & & & $\begin{array}{l}-1.71 * * \\
(-2.38)\end{array}$ \\
\hline AbsLandDiff & & & $\begin{array}{c}0.01 \\
(0.02)\end{array}$ \\
\hline Constant & $\begin{array}{l}-24.97 * * * \\
(-7.85)\end{array}$ & $\begin{array}{c}-17.87 * * * \\
(-5.36)\end{array}$ & $\begin{array}{l}-16.86^{* * *} \\
(-4.67)\end{array}$ \\
\hline Number of obs. & 1738 & 1501 & 1121 \\
\hline Number of var. & 102 & 101 & 93 \\
\hline $\mathrm{R}$-squared & 0.9518 & 0.9524 & 0.9485 \\
\hline
\end{tabular}

Notes: T-statistics in parentheses; * **,*** denote significance at the 10,5 , and $1 \%$ level, respectively.

sults at the $10 \%$ level; however, these significant results all have negative signs. Model II confirms the negative result of Model I of the GDP per capita differences, while the variable capturing the effect of the difference in human capital also shows statistically significant negative results. The effect of population density is insignificant. In case of Model III, the coefficient of physical capital is insignificant, while the differences in human capital and land area also have statistically significant negative coefficients. Consequently, based on simple OLS regressions, we found that differences in factor endowments result in less bilateral trade, therefore we can reject the H-O model and conclude that the bilateral exports of Hungary correspond to the Linder theorem.

However, the regression results of simple OLS tend to be biased (see, e.g., Mátyás 1996; Baldwin - Taglioni 2006). Therefore, in order to get less biased 
results and control for multilateral resistance, we expanded our model specifications with country and time fixed effects. These dummy variables control for country and time-specific fixed effects, therefore the results of the original explanatory variables are more accurate. Table 4 contains the results for the expanded model.

Adding country- and time-specific dummy variables results in higher Rsquared values and more statistically significant (and less biased) results. The effect of Hungary's GDP on its export is much greater than in the case of the OLS regression, and it is almost twice as much as the effect of the trading partner's GDP in Model II, while Model I shows an even greater difference. Since the major difference between our models lies in the time periods after controlling for factor endowments, this result suggests that in the post-crisis era, the impact of Hungarian GDP on its export has grown significantly. In contrast, fixed effects had a smaller impact on the size of the coefficients of distance, but the effect of a common border (a factor related to geographical proximity) increased significantly. Based on the results of the expanded model, sharing a common border increased Hungary's bilateral export by $480 \%$ in the period of $1993-2007$, and this effect multiplied in the case of the sample for $1993-2014 .{ }^{10}$ In the meantime, having a trade agreement had a smaller positive (23-48\%) impact on trade for the period following the EU accession of 2004.

The results for the factor endowment variables are very similar to those in the simple OLS regression. Absolute relative endowment shows significant negative values in both Models I and II, and differences in human capital have significant negative effects on bilateral export in both Models II and III. The coefficients for population density, physical capital, and land area are insignificant in the expanded model.

Concluding the results of the empirical analysis, we can assert that we found strong evidence supporting that the bilateral export of Hungary is more significant with countries with similar factor endowments, and therefore we can reject the Heckscher-Ohlin model.

\section{CONCLUSIONS}

The purpose of this paper was to highlight the most important factors affecting the foreign trade of Hungary, with an emphasis on factor endowments. The paper did not analyse the total export of Hungary, but those permanent trade linkages which existed for 19 years without a break. Therefore our results are not biased

10 Calculated as $100 *[\exp ($ VALUE) -1$]$. 
by those trade relations that lasted for just a few years and included only a few product groups. The limitations of our results arise from the fact that we applied gross merchandise data due to limited data availability on both value-added trade data and data on trade in services.

Regarding the permanent trade relations of Hungary, the increase in the national income of Hungary or a given trading partner had a positive effect on the export of Hungary. In contrast, distance as a proxy of trade costs had negative effect on foreign trade; on average, a $1 \%$ increase in distance decreases bilateral trade by $1.4-1.5 \%$. Sharing a common border increases trade significantly, while free trade agreements have a positive effect. Hungary trades about $30 \%$ more with countries that signed a trade agreement, although in order to have a more accurate calculation on the effect of FTAs, a refinement on the variable would be needed as the literature of trade agreements suggests.

We managed to find a convincing answer to our research question about which trade theory corresponds to the foreign trade of Hungary. Although having a 45$50 \%$ foreign factor content in export would support the Heckscher-Ohlin model, as foreign value-added comes from countries having dissimilar factor endowments, our results unanimously support the Linder-type models. In all three model approaches, it was clearly outlined that Hungary tends to trade more with similar countries and that high differences in factor endowments cause less bilateral trade between Hungary and its trading partners. Therefore, the Heckscher-Ohlin model is rejected, regardless of the fact that foreign content is quite high in the case of Hungarian export.

The results are consistent with recent findings in the theoretical and empirical literature of intra-industry trade (see, inter alia, Cabral et al. 2013), which reinforce the importance of relative endowment similarities in the two-way trade of horizontally differentiated goods and also point to the fact that as opposed to some former rather "monotonic" explanations of vertical intra-industry trade, the share of vertical two-way flows grows with differences in factor endowments only until these differences remain limited.

Our findings not only contribute to the empirical studies on trade theory, but may also have further implications for policymakers. In a country where foreign trade is one of the most important drivers of the economy, the increase in trade volumes may have a trickle-down effect. If a country's foreign trade corresponds to the Linder theorem, closer trade relations with similar countries may have a positive effect on the volume of trade and thus on the economy. Governments recognising this phenomenon may redirect their trade policies and focus on pursuing trade and investment negotiations with countries that have similar factor endowments. 


\section{REFERENCES}

Ahmad, N. (2013): Estimating Trade in Value-Added: Why and How? In: Elms, D. K. - Low, P. (eds): Global Value Chains in a Changing World, pp. 85-108. Switzerland: WTO Publications.

Anderson, J. E. (1979): A Theoretical Foundation for the Gravity Equation. American Economic Review, 69(1): 106-116.

Anderson, J. E. (2010): The Gravity Model. Working Paper, No. 16576, National Bureau of Economic Research.

Anderson, J. E. - Van Wincoop, E. (2001): Gravity with Gravitas: A Solution to the Border Puzzle. Working Paper, No. 8079. National Bureau of Economic Research.

Antonucci, D. - Manzocchi, S. (2006): Does Turkey Have a Special Trade Relation with the EU? A Gravity Model Approach. Economic Systems, 30(2): 157-169.

Antweiler, W. - Trefler, D. (2002): Increasing Returns and All That: A View from Trade. American Economic Review, 92(1): 93-119.

Azhar, A. K. M. - Elliott, R. J. R. (2004): On the Measurement of Vertical and Horizontal IntraIndustry Trade: A Geometric Exposition. Graduate School of Management Research Paper Series, GRPS, 03/04, University Putra, Malaysia. Presented at the European Trade Study Group $6^{\text {th }}$ Annual Conference, ETSG, September 9-11, Nottingham

Baldwin, R. - Taglioni, D. (2006): Gravity for Dummies and Dummies for Gravity Equations. Working Paper, No. 12516, National Bureau of Economic Research.

Baskaran, T. - Blöchl, F. - Brück, T. - Theis, F. J. (2011): The Heckscher-Ohlin Model and the Network Structure of International Trade. International Review of Economics \& Finance, 20(2): $135-145$.

Batra, A. (2006): India's Global Trade Potential: The Gravity Model Approach. Global Economic Review, 35(3): 327-361.

Bergstrand, J. H. (1989): The Generalized Gravity Equation, Monopolistic Competition, and the Factor-Proportions Theory in International Trade. Review of Economics and Statistics, 71(1): 143-153.

Bernard, A. B. - Jensen, J. B. - Schott, P. K. (2003): Falling Trade Costs, Heterogeneous Firms, and Industry Dynamics. Working Paper, No. 9639. National Bureau of Economic Research.

Bernard, A. B. - Jensen, J. B. - Redding, S. J. - Schott, P. K. (2007): Firms in International Trade. Working Paper, No. 13054, National Bureau of Economic Research.

Bock, Gy. (1995): A hazai külgazdasági liberalizáció elörehaladása és megalapozottsága (Progress and Grounding of the Domestic Foreign Trade Liberalisation). Külgazdaság, 39(9): 4-20.

Brülhart, M. (2009): An Account of Global Intraindustry Trade, 1962-2006. The World Economy, 32(3): 401-459.

Cabral, M. - Falvey, R. - Milner, C. (2013): Endowment Differences and the Composition of IntraIndustry Trade. Review of International Economics, 21(3): 401-418.

Costinot, A. - Donaldson, D. (2012): Ricardo's Theory of Comparative Advantage: Old Idea, New Evidence. Working Paper, No. 17969, National Bureau of Economic Research.

Davis, D. R. - Weinstein, D. E. (2001): An Account of Global Factor Trade. American Economic Review, 91(5): 1423-1453.

Davis, D. R. - Weinstein, D. E. - Bradford, S. C. - Shimpo, K. (1997): Using International and Japanese Regional Data to Determine when the Factor Abundance Theory of Trade Works. American Economic Review, 87(3): 421-446.

Dixit, A. K. - Stiglitz, J. E. (1977): Monopolistic Competition and Optimum Product Diversity. The American Economic Review, 297-308. 
Eaton, J. - Kortum, S. (2002): Technology, Geography, and Trade. Econometrica, 70(5): 17411779.

Eicher, T. S. - Henn, C. - Papageorgiou, C. (2012): Trade Creation and Diversion Revisited: Accounting for Model Uncertainty and Natural Trading Partner Effects. Journal of Applied Econometrics, 27(2): 296-321.

Erdey, L. - Pöstényi, A. (2014): Determinants of Foreign Trade of Hungary: Trade Theory and the Gravity Model. In: Bóta, G. - Ormos, M. (eds): SSEM EuroConference 2014: The International Conference on Emerging Markets Business, Economics and Finance, pp. 32-66.

Falvey, R. E. (1981): Commercial Policy and Intra-Industry Trade. Journal of International Economics, 11(4): 495-511.

Falvey, R. E. - Kierzkowski, H. (1987): Product Quality, Intra-Industry Trade and (Im)Perfect Competition. In: Kierzkowski, H. (ed.): Protection and Competition in International Trade: Essays in Honor of W. M. Corden. Oxford University Press, pp. 143-161.

Flam, H. - Helpman, E. (1987): Vertical Product Differentiation and North - South Trade. The American Economic Review, 77(5): 810-822.

Fontagné, L. - Freudenberg, M. - Gaulier, G. (2005): Disentangling Horizontal and Vertical IntraIndustry Trade. CEPII document de travail, 2005-10, Paris: Centre d'Etudes Prospectives et d'Informations Internationales.

Gabszewicz, J. - Shaked, A. - Sutton, J. - Thisse, J.-F. (1981): International Trade in Differentiated Products. International Economic Review, 22(3): 527-534.

Gabszewicz, J. - Turrini, A. (1997): Workers' Skills, Product Quality and Industry Equilibrium. International Journal of Industrial Organisation, 18(4): 575-593.

Grubel, H. G. - Lloyd, P. J. (1975): Intra-Industry Trade: The Theory and Measurement of International Trade in Differentiated Products. London: Macmillan Press.

Haucap, J. - Wey, C. - Bambold, J. (2000): Location Costs, Product Quality and Implicit Franchise Contracts. Journal of International Economics, 52(1): 69-87.

Hausmann, R. - Hidalgo, C. A. - Stock, D. P. - Yildirim, M. A. (2014): Implied Comparative Advantage. CID Working Paper, No. 276.

Helpman, E. - Krugman, P. R. (1985): Market Structure and Foreign Trade: Increasing Returns, Imperfect Competition, and the International Economy. Cambridge, Massachusetts and London, England: MIT press.

Köves, A. (2003): A KGST-kereskedelemtöl az EU-csatlakozásig. A kereskedelmi reorientáció néhány főbb kérdése a rendszerváltó országokban, különös tekintettel Magyarországra, I. Kontinuitás és diszkontinuitás a külkereskedelmi kapcsolatokban (From CMEA Trading To EU Accession. Issues of Trade Reorientation in the System-Changing Countries, Especially Hungary. I. Continuity and Discontinuity in Trade Relations). Közgazdasági Szemle, 50(7): 635-653.

Krugman, P. R. (1979): Increasing Returns, Monopolistic Competition, and International Trade. Journal of International Economics, 9(4): 469-479.

Krugman, P. R. (1981): Intraindustry Specialization and the Gains from Trade. The Journal of Political Economy, 89(5): 959.

Krugman, P. R. - Obstfeld, M. (1988): International Economics: Theory and Policy. Glenview: Scott Foresman.

Lancaster, K. (1979): Variety, Equity, and Efficiency: Product Variety in an Industrial Society. New York: Columbia University Press.

Lancaster, K. (1980): Intra-Industry Trade under Perfect Monopolistic Competition. Journal of International Economics, 10(2): 151-175. 
Leamer, E. E. (1980): The Leontief Paradox, Reconsidered. The Journal of Political Economy, 88(3): 495-503.

Leamer, E. E. (1992): Testing Trade Theory. Working Paper, No. 3957. National Bureau of Economic Research.

Leontief, W. (1953): Domestic Production and Foreign Trade; The American Capital Position ReExamined. Proceedings of the American Philosophical Society, pp. 332-349.

Linder, S. B. (1961): An Essay on Trade and Transformation. Stockholm: Almquist and Wiksell.

Mátyás, L. (1997): Proper Econometric Specification of the Gravity Model. The World Econo$m y, 20(3): 363-368$.

Melitz, M. (2003): The Impact of Trade on Aggregate Industry Productivity and Intra-Industry Reallocations. Econometrica, 71(6): 1695-1725.

Miroudot, S. - Sauvage, J. - Shepherd, B. (2013): Measuring the Cost of International Trade in Services. World Trade Review, 12(4): 719-735.

Montenegro, C. E. - Soto, R. (1996): How Distorted is Cuba's Trade? Evidence and Predictions from a Gravity Model. Journal of International Trade \& Economic Development, 5(1): 45-68.

Motta, M. (1994): International Trade and Investment in a Vertically Differentiated Industry. International Journal of Industrial Organization, 12(2): 179-196.

Nagy, A. (1995): A behozatal liberalizálása Magyarországon (Liberalization of Imports in Hungary). Közgazdasági Szemle, 42(5): 454-470.

Rahman, M. M. (2003): A Panel Data Analysis of Bangladesh's Trade: The Gravity Model Approach. Proceedings of the 5th Annual Conference of the European Trade Study Group (ETSG2003). 11-13 September, Madrid.

Reimer, J. J. - Hertel, T. W. (2010): Nonhomothetic Preferences and International Trade. Review of International Economics, 18(2): 408-425.

Schumacher, D. (2003): Home Market and Traditional Effects on Comparative Advantage in a Gravity Approach. DIW Diskussionspapiere, No. 344, Berlin.

Shaked, A. - Sutton, J. (1984): Natural Oligopolies and International Trade. In: Kierzkowski, H. (ed.): Monopolistic Competition and International Trade. Oxford: Oxford University Press, pp. 34-50.

Shaked, A. - Sutton, J. (1987): Product Differentiation and Industrial Structure. The Journal of Industrial Economics, 36(2): 131-146.

Shirotori, M. - Tumurchudur, B. - Cadot, O. (2010): Revealed Factor Intensity Indices at the Product Level. UNCTAD.

Sohn, C. H. (2005): Does the Gravity Model Explain South Korea's Trade Flows? Japanese Economic Review, 56(4): 417-430.

Spence, M. (1976): Product Selection, Fixed Costs, and Monopolistic Competition. The Review of Economic Studies, 43(2): 217-235.

Tinbergen, J. (1962): Shaping the World Economy; Suggestions for an International Economic Policy. New York: Twentieth Century Fund.

Trefler, D. (1993): International Factor Price Differences: Leontief was Right! Journal of Political Economy, 101(3): 961-987.

Trefler, D. (1995): The Case of the Missing Trade and Other Mysteries. The American Economic Review, 85(5): 1029-1046.

Trefler, D. - Zhu, S. C. (2010): The Structure of Factor Content Predictions. Journal of International Economics, 82(2): 195-207.

Vanek, J. (1968): The Factor Proportions Theory: The n-Factor Case. Kyklos, 21(4): 749-756. 
WTO (1998): Trade Policy Review of Hungary. United Nations Report by the Secretariat, WT/ TPR/S/40, June 15.

WTO (2015): World Economic Situation and Prospects 2015. New York: United Nations.

Yip, T. L. (2012): Seaborne Trade between Developed and Developing Countries. The Asian Journal of Shipping and Logistics, 28(3): 369-389. 